\title{
The parent drugs chloroquine and hydroxychloroquine do not inhibit human CYP3A activity in vitro
}

\author{
Xia Li ${ }^{1}$ - Rainer Höhl ${ }^{2}$ - Fritz Sörgel ${ }^{3,4} \cdot$ Uwe Fuhr $^{1}$ (D \\ Received: 25 April 2020 / Accepted: 2 June 2020 / Published online: 18 June 2020 \\ (C) The Author(s) 2020
}

To the Editor,

Among 796 clinical trials to treat COVID-19, chloroquine and hydroxychloroquine account for a large fraction with 46 trials for chloroquine and 120 trials for hydroxychloroquine (https://clinicaltrials.gov/ as of 24 April 2020). Despite the lack of reliable clinical data, due to their significant inhibitory effects on viral cell entry and replication [1], both drugs have been recommended to treat patients diagnosed as mild, moderate, and severe cases of COVID-19 pneumonia [2]. However, for critically ill patients, co-medications are usually required. Unfortunately, there is little information on potential drug-drug interactions caused by chloroquine and hydroxychloroquine.

During compassionate treatment of two adult COVID-19 patients with hydroxychloroquine (day 1: $2 \times 400 \mathrm{mg}$, thereafter $2 \times 200 \mathrm{mg}$ daily) and clarithromycin $(2 \times 500 \mathrm{mg}$ daily $)$, routine therapeutic drug monitoring on days 2 and/or 3 of treatment showed unexpectedly high clarithromycin concentrations (> $10 \mathrm{mg} / \mathrm{L}$ around the end of infusion). The patients were on mechanical ventilation but had no renal failure and were of normal body weight. Clarithromycin was given for suspected bacterial superinfection to cover atypical pathogens of a possible community-acquired pneumonia. The finding indicates that hydroxychloroquine may inhibit cytochrome

Uwe Fuhr

uwe.fuhr@uk-koeln.de

1 Faculty of Medicine and University Hospital Cologne, Center for Pharmacology, Department I of Pharmacology, University of Cologne, Gleueler Straße 24, 50931 Cologne, Germany

2 Institute for Clinical Hygiene, Medical Microbiology and Clinical Infectiology, Paracelsus Medical Private University, Nuremberg Hospital, Nuremberg, Germany

3 IMBP-Institute for Biomedical and Pharmaceutical Research, Nürnberg, Heroldsberg, Germany

4 Institute of Pharmacology, West German Heart and Vascular Centre, University of Duisburg-Essen, Essen, Germany
P450 (CYP)3A, since clarithromycin is primarily metabolized by CYP3A [3]. In addition, hydroxychloroquine was reported to inhibit CYP2D6-mediated metabolism of metoprolol in vivo [4], and chloroquine also decreased CYP2D6 activity [5]. However, there is no data on a potential inhibition of CYP3A4 by chloroquine and/or hydroxychloroquine.

Therefore, an in vitro assay to assess inhibition of CYP3A4 by the two drugs was performed using a published method (see supplementary materials of reference [6]). The formation of 1'-hydroxymidazolam from midazolam was used as the CYP3A4 probe reaction, as recommended by the FDA and EMA [7, 8]. A $250 \mathrm{mg}$ chloroquine phosphate tablet (Avloclor ${ }^{\circledR} 250 \mathrm{mg}$ tablets, Alliance Pharma PLC, Wiltshire, UK) or a $200 \mathrm{mg}$ hydroxychloroquine sulphate tablet (Quensyl® 200 mg tablets, Sanofi-Aventis, Paris, France) was dissolved by the addition of $2 \mathrm{~L}$ of water to obtain the respective stock solutions. $K_{i}$ values were determined to assess the effect of chloroquine and hydroxychloroquine on CYP3A4 by incubating a range of substrate (i.e., 0.2, 0.6, $2,6,12,20 \mu \mathrm{M})$ and inhibitor concentrations $(0,0.6,1.25$, $2.5,5,10,20,40 \mu \mathrm{M})$ with $1.85 \mathrm{pmol} / \mathrm{ml} \mathrm{CYP} 3 \mathrm{~A} 4$ for 8 minutes. The assays were carried out in duplicate. The resulting metabolite was quantified by LC-MS/MS as described [6]. Datasets were analyzed using GraphPad Prism 7 (GraphPad, La Jolla, CA, USA) [9].

$K_{\mathrm{m}}$ and $V_{\max }$ values for midazolam hydroxylation in the two inhibition assays were very similar, i.e., $0.72 \mu \mathrm{M}$ and $20.0 \mathrm{pmol} 1$ 1'-OH-MDZ/min/pmol CYP3A4 for the chloroquine experiment, and $0.69 \mu \mathrm{M}$ and $19.4 \mathrm{pmol} 11^{\prime}-\mathrm{OH}-\mathrm{MDZ} /$ $\mathrm{min} / \mathrm{pmol} \mathrm{CYP3A4}$ for hydroxychloroquine. For midazolam concentrations below $2 \mu \mathrm{M}$, there was no apparent effect of a range of concentrations of chloroquine and hydroxychloroquine on CYP3A4 activity (Fig. 1). At higher midazolam concentrations, enzyme activity showed a trend to increase with higher concentrations of both chloroquine and hydroxychloroquine. While the mechanism for this observation is unknown, clearly there was no inhibitory effect. The goodness of fit indicated that the nonlinear competitive 
Fig. 1 Dixon plot of in vitro assay for inhibition of CYP3A4 by chloroquine (a) and hydroxychloroquine (b). v, enzyme activity rate. $1^{\prime}-\mathrm{OH}-$ MDZ, 1'-OH-midazolam. Lines indicate the fits according to the competitive inhibition model obtained from the entire dataset
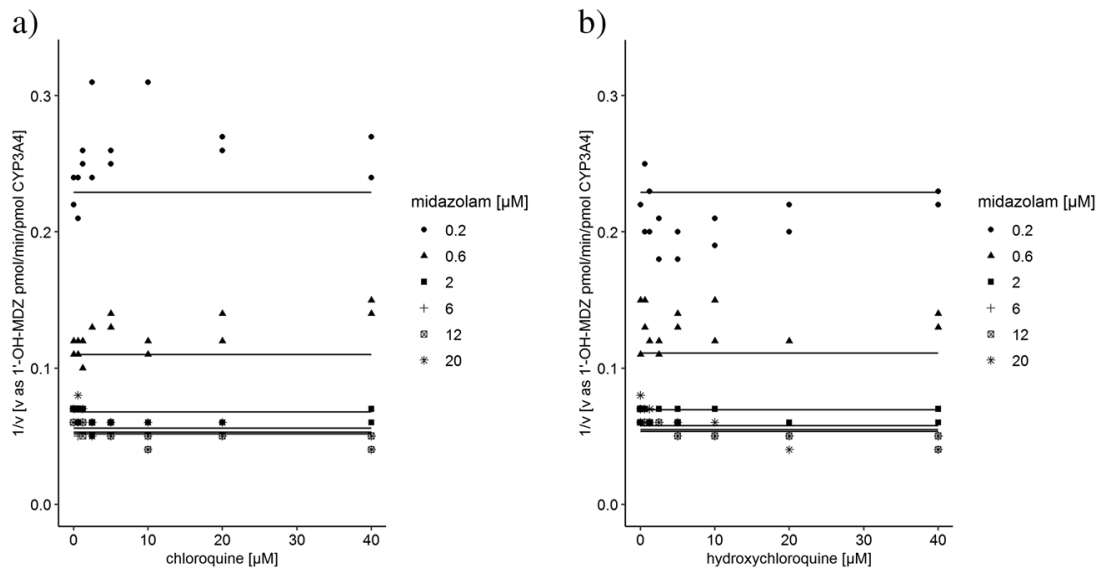

inhibition model described the data reasonably well, and also respective $K_{i}$ values (i.e., $9.18 \times 10^{95} \mu \mathrm{M}$ for chloroquine and $1.14 \times 10^{88} \mu \mathrm{M}$ for hydroxychloroquine) approaching infinity clearly showed that both drugs did not cause inhibitory action on CYP3A4.

The current in vitro assay demonstrated that chloroquine and hydroxychloroquine do not inhibit CYP3A4 activity, excluding the possibility that the parent drugs cause the observed high clarithromycin exposure by this mechanism. However, we cannot exclude whether metabolites of these drugs may inhibit CYP3A. The reason for high clarithromycin concentrations when co-administered with hydroxychloroquine should be further explored.

Acknowledgements Open access funding provided by Projekt DEAL.

Open Access This article is licensed under a Creative Commons Attribution 4.0 International License, which permits use, sharing, adaptation, distribution and reproduction in any medium or format, as long as you give appropriate credit to the original author(s) and the source, provide a link to the Creative Commons licence, and indicate if changes were made. The images or other third party material in this article are included in the article's Creative Commons licence, unless indicated otherwise in a credit line to the material. If material is not included in the article's Creative Commons licence and your intended use is not permitted by statutory regulation or exceeds the permitted use, you will need to obtain permission directly from the copyright holder. To view a copy of this licence, visit http://creativecommons.org/licenses/by/4.0/.

\section{References}

1. Wang M, Cao R, Zhang L, Yang X, Liu J, Xu M, Shi Z, Hu Z, Zhong W, Xiao G (2020) Remdesivir and chloroquine effectively inhibit the recently emerged novel coronavirus (2019-nCoV) in vitro. Cell Res 30:269-271. https://doi.org/ $10.1038 / \mathrm{s} 41422-020-0282-0$

2. Pneumonia. D of $\mathrm{S}$ and $\mathrm{T}$ of GP and $\mathrm{HC}$ of GP for chloroquine in the treatment of novel coronavirus (2020) Expert consensus on chloroquine phosphate for the treatment of novel coronavirus pneumonia. Zhonghua Jie $\mathrm{He} \mathrm{He} \mathrm{Hu} \mathrm{Xi} \mathrm{Za}$ Zhi 43:185-188. https://doi.org/10.3760/cma.j.issn.1001-0939. 2020.03.009

3. Rodvold KA (1999) Clinical pharmacokinetics of clarithromycin. Clin Pharmacokinet 37:385-398. https://doi.org/10.2165/ 00003088-199937050-00003

4. Somer M, Kallio J, Pesonen U, Pyykkö K, Huupponen R, Scheinin M (2000) Influence of hydroxychloroquine on the bioavailability of oral metoprolol. Br J Clin Pharmacol 49:549-554. https://doi.org/10. 1046/j.1365-2125.2000.00197.x

5. Adedoyin A, Frye RF, Mauro K, Branch RA (1998) Chloroquine modulation of specific metabolizing enzymes activities: investigation with selective five drug cocktail. Br J Clin Pharmacol 46:215219. https://doi.org/10.1046/j.1365-2125.1998.00765.x

6. Li X, Frechen S, Moj D, et al (2019) A physiologically based pharmacokinetic model of voriconazole integrating time-dependent inhibition of CYP3A4, genetic polymorphisms of CYP2C19 and predictions of drug-drug Interactions. Clin Pharmacokinet 1-28. https:// doi.org/10.1007/s40262-019-00856-Z

7. U.S. Food and Drug Administration Drug Development and Drug Interactions: Table of Substrates, Inhibitors and Inducers | FDA. https://www.fda.gov/drugs/drug-interactions-labeling/drugdevelopment-and-drug-interactions-table-substrates-inhibitors-andinducers\#table 1-2. Accessed 24 Apr 2020

8. European Medicines Agency Guideline on the investigation of drug interactions. Published June, 2012. https://www.ema.europa.eu/en/ documents/scientific-guideline/guideline-investigation-druginteractions_en.pdf

9. GraphPad Software (1995) GraphPad curve fitting guide

Publisher's note Springer Nature remains neutral with regard to jurisdictional claims in published maps and institutional affiliations. 